\title{
The vegetation of Tshanini Game Reserve and a comparison with equi- valent units in the Tembe Elephant Park in Maputaland, South Africa
}

\author{
J.Y. Gaugris, W.S. Matthews, M.W. van Rooyen and J. du P. BothMa
}

Gaugris, J.Y., W.S. Matthews, M.W. van Rooyen and J. du P. Bothma. 2004. The vegetation of Tshanini Game Reserve and a comparison with equivalent units in the Tembe Elephant Park in Maputaland, South Africa. Koedoe 47(1): 9-29. Pretoria. ISSN 00756458.

\begin{abstract}
An analysis of the plant communities of the to be proclaimed Tshanini Game Reserve and their relation with selected similar plant communities of Tembe Elephant Park are presented. The study area lies $6 \mathrm{~km}$ due south of Tembe Elephant Park within the Maputaland Centre of Plant Endemism, which is part of the Maputaland-Pondoland region recognised by the IUCN as a centre of Plant Diversity. A Braun-Blanquet classification on 51 random sample plots revealed eight distinct, mainly woodland plant associations. Vegetation distribution follows the same patterns as described in Tembe Elephant Park. Plant communities and subcommunities are mapped, described and compared to similar plant communities in Tembe Elephant Park to detect differences between protected and unprotected areas. Results from the qualitative comparison showed $>50 \%$ similarity between equivalent units and results from the quantitative comparison showed $>25 \%$ to $50 \%$ similarity between equivalent units. Mueller-Dombois and Ellenberg (1974) regard $25 \%$ as the lower threshold value to indicate similar associations. The observed differences may relate to animal and human utilisation.
\end{abstract}

Key words: plant communities, Sand Forest, similarity indices, Tembe Elephant Park, Tshanini Game Reserve

J.Y. Gaugris and J. du P. Bothma, Centre for Wildlife Management, University of Pretoria, Pretoria, 0002 Republic of South Africa; W.S. Matthews, Tembe Elephant Park, Ezemvelo KwaZulu-Natal Nature Wildlife, Private Bag 356, KwaNgwanase, 3973 Republic of South Africa; M.W. van Rooyen Department of Botany, University of Pretoria, Pretoria, 0002 Republic of South Africa.

\section{Introduction}

The Tembe Elephant Park was proclaimed in 1983 after negotiations between the then KwaZulu Bureau of Natural Resources and the Tembe Tribal Authority in consultation with the local communities of northern Maputaland, KwaZulu-Natal, South Africa. The park boundaries were subsequently fenced and animal numbers started to increase. The fence has kept the utilisation of renewable natural resources by the local communities at bay for the past 19 years. In this period, the vegetation of the park has been utilised only by the indigenous fauna, but it has been affected by management decisions and possibly also regional environmental changes.
The Tshanini Game Reserve was established in 2000 on some land of the community of Manqakulane, but it has not yet been registered. The reserve's creation developed from the initiative of the local community, from as far back as the creation of Tembe Elephant Park. The ideal of the Manqakulane people was to create their own reserve on their own land to counteract high unemployment and to raise funds for the development of the community through ecotourism. For the past 20 years, the land where the Tshanini Game Reserve has been established was utilised by the local people for wood harvesting, livestock grazing, hunting, fruit and honey gathering, and subsistence cultivation where this was viable. It is presumed that large ungulate numbers have always been low in Tshanini 


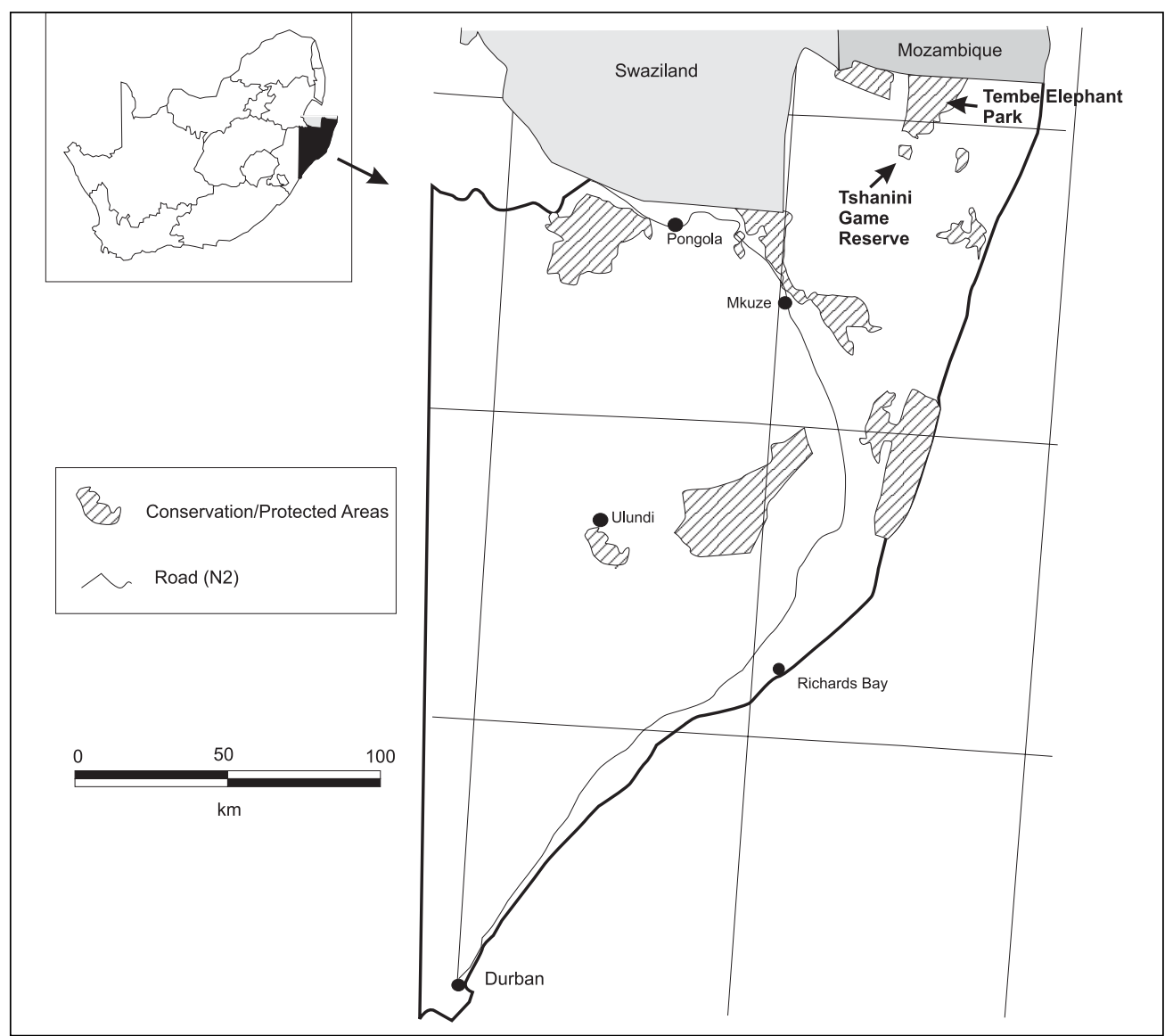

Fig. 1. Map of Maputaland with the locations of Tembe Elephant Park and Tshanini Game Reserve in northern KwaZulu-Natal, South Africa.

Game Reserve, due to the absence of standing water. However, hunting pressure has affected the larger mammal populations, and only small, secretive antelope such as the suni Neotragus moschatus and red duiker Cephalophus natalensis have survived there.

The Tembe Elephant Park and the Tshanini Game Reserve are underlain by the same type of soil and they share the same broad vegetation types. Moll (1977) distinguished the Pallid Bushveld and the Sand Forest Zones in the area, whereas Low \& Rebelo (1980) recognised the Subhumid Lowveld Bushveld of the Savanna Biome and the Sand Forest of the Forest Biome. The two reserves lie close to each other with the northern boundary of Tshanini Game Reserve some $6 \mathrm{~km}$ due south of the southern boundary of Tembe Elephant Park. Both of these conservation areas lie in the core of the Maputaland Centre of Plant Endemism as described by Van Wyk (1996). In both reserves a rare forest type, known as Sand Forest occurs (Van Wyk 1996; Van Rensburg et al. 1999; Kirkwood \& Midgley 1999; Matthews et al. 2001; Van Wyk \& Smith 2001). The Sand Forest in this particular area is further defined as the eastern Sand Forest by MacDevette et al. (1989) and Kirkwood \& Midgley (1999). In South Africa and in Mozambique, this forest type is restricted to 
the ancient coastal dune cordons of northern KwaZulu-Natal, and it is home to many rare and unusual plant and animal species (Kirkwood \& Midgley 1999; Van Wyk \& Smith 2001). Sand Forest in South Africa covers only $354 \mathrm{~km}^{2}$, of which $44 \%$ is conserved (Low \& Rebelo 1998) with the largest protected area in South Africa in the Tembe Elephant Park (McGeogh et al. 2002). The major part of this vegetation type is found in Mozambique but the extent of it is unknown at present, because of a lack of detailed studies. Cattle grazing, firewood demands and elephant Loxodonta africana impact are the main identified threats for the Sand Forest (Van Wyk 1996; Van Rensburg et al. 1999).

The human population growth rate in Maputaland is high, increasing both by natural growth and immigration, despite a high mortality rate from the AIDS epidemic. Roads have been constructed through the communities, and safe drinking water is provided. Although these are laudable rural developments, they may become a threat to the conservation of the remote and less exploited areas of northern Maputaland.

Matthews et al. (2001) did a complete vegetation survey of Tembe Elephant Park, and suggested that their data could be used for management and land use planning for other similar areas in Maputaland. However, the questions are to what extent has human pressure affected the vegetation in comparison with wildlife use; can the vegetation of Tembe Elephant Park be regarded as representative of similar areas in Maputaland and how well did the Sand Forest fare outside a formal conservation area? In this paper we aim to provide ecological and floristic data specifically for the Tshanini Game Reserve by identifying, characterising, interpreting and mapping the major vegetation units that occur there. Further objectives are to compare the vegetation of Tshanini Game Reserve with similar units in Tembe Elephant Park in terms of species composition and abundance, and to relate the perceived changes to differences in utilisation pressure.

\section{Study area}

Tshanini Game Reserve is 2420 ha in extent and its northern boundary lies $6 \mathrm{~km}$ due south of the southern boundary of Tembe Elephant Park (Fig. 1). The area consists mainly of a sandy plain that is interspersed with ancient littoral dunes, and is covered by an open to closed woodland with patches of short to tall Sand Forest (Fig. 2).

The area covered by Tshanini Game Reserve is unfenced and therefore subject to human influence. Cattle grazing with small herds, rarely exceeding 20 heads, and wood collecting, either for construction or fire, are the most important forms of natural resource utilisation. Other less intensive forms of use include fruit gathering, the collecting of honey and thatching grass, and hunting of birds and mammals. Until 1995, the eastern portion of Tshanini was still utilised for agriculture, with some large fields cut into the woodland or forest. The Manqakulane community resided on the eastern boundary of the reserve until 1990, when they moved to $3 \mathrm{~km}$ east of the eastern boundary of Tshanini Game Reserve. The relocation followed the installation of a governmental clean water supply to the local communities. The new location of the human settlements on the southern part of the Muzi Swamp has a better soil potential for agriculture. The community of Manqakulane today controls an area of just over 10000 ha, with a population of approximately 700 people in 110 households that are concentrated around the Muzi Swamp.

\section{Topography}

Tshanini Game Reserve lies centrally in the southernmost portion of the Mozambican Coastal Plain between the Lebombo Mountains in the west and the Indian Ocean in the east. Ancient littoral dunes that run in a broadly north to south direction are interspersed with inter-dune depressions. To the west of the reserve a seepage line forms the source of the Nhlole River, a non-perennial seepage line winding to Makane's Drift and flowing into the Pongola River. The seepage 


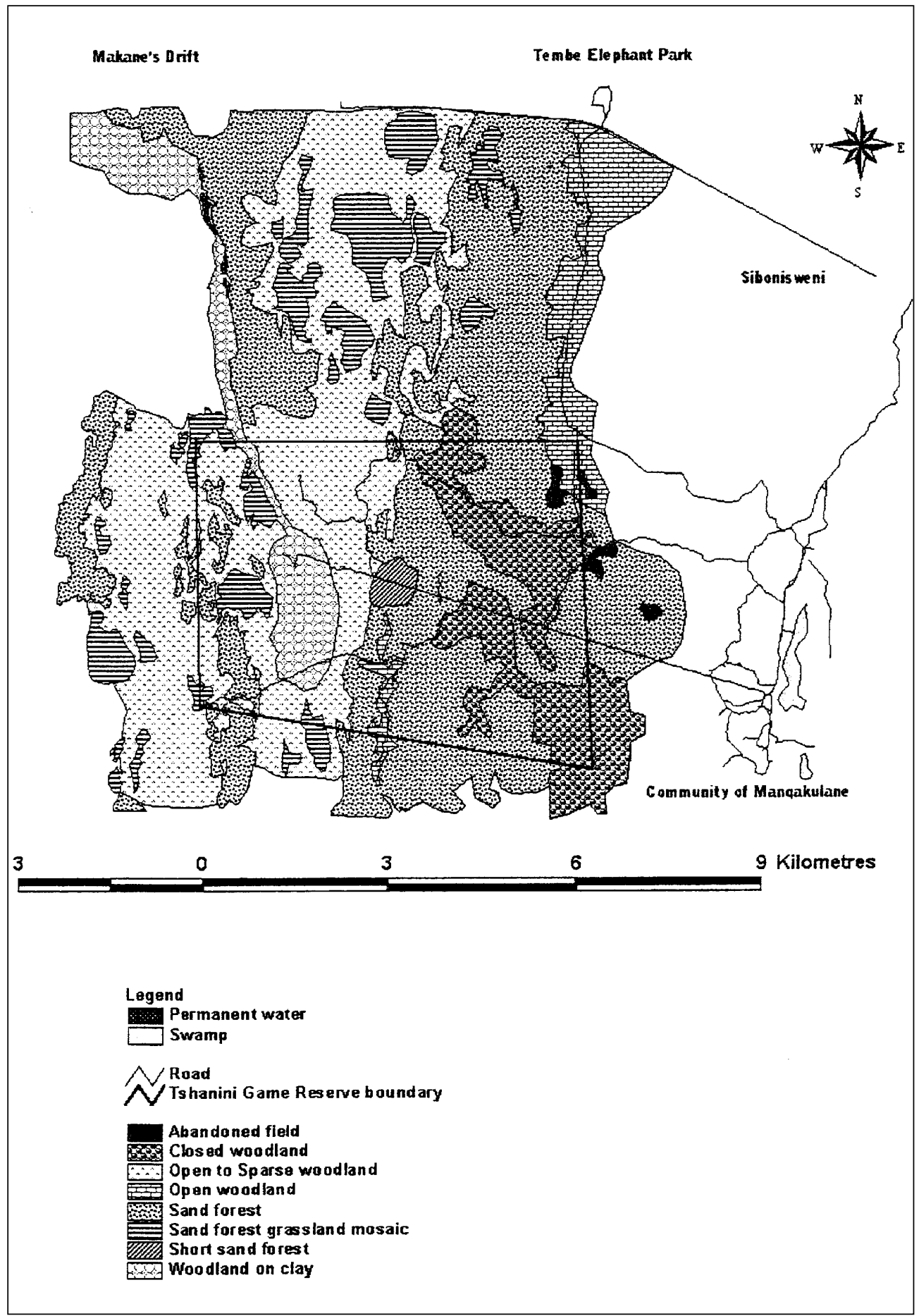

Fig. 2. The vegetation of the Tshanini Game Reserve and surrounding area in Maputaland, northern KwaZulu-Natal, South Africa. 
line runs from the southeast to the northwest.

The Tshanini Game Reserve has a mean altitude of $80 \mathrm{~m}$ above sea level, and two main ancient littoral dunes occur in it. The dune on the eastern boundary is the southern extension of Nhlela Ridge that extends into the western portion of Tembe Elephant Park. A beacon is positioned on top of the ridge at an altitude of $103 \mathrm{~m}$ above sea level. A second dune runs along the western boundary at an altitude of $95 \mathrm{~m}$ above sea level. Between the two main dunes, a third but smaller dune formation is found that starts in the middle of Tshanini Game Reserve and increases in height towards the southern-central part of the reserve. The Nhlole River lies to the east of the western dune cordon, and the lowest point of the reserve is $64 \mathrm{~m}$ above sea level in the northeastern corner.

\section{Climate}

Rainfall and temperature data for the weather station at Sihangwane at the entrance of Tembe Elephant Park $\left(32.42388^{\circ} \mathrm{E}, 27.04316^{\circ} \mathrm{S}\right)$ appear in Fig. 3. Maputaland lies in a transition zone between the tropics to the north and subtropics to the south. The summers are hot and the winters cool to warm. The summer months are the wettest, although rainfall occurs throughout the year. In the drier winter months, morning mist is a common phenomenon especially in the swamp areas. The relative humidity of the air in summer is higher than in winter (Matthews et al. 2001).

\section{Geology}

The underlying geology of Tshanini Game Reserve consists of Cretaceous siltstone units that form the base of the Mozambican Coastal Plain. This formation is overlain by sediments of Miocene and Pleistocene origin. The Maputaland Group overlies the latter. On top of this formation lie the marine, littoral and coastal dune deposits that were formed by successive marine transgressions and regressions. The oldest dunes of the

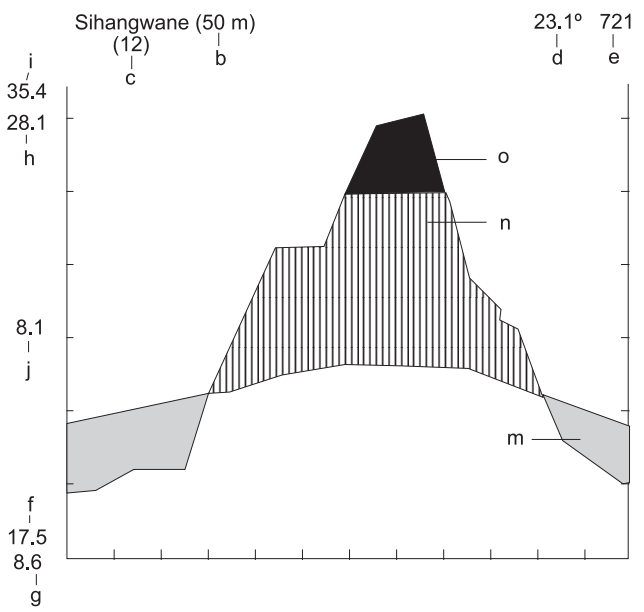

Fig. 3. Climatogram of the Sihangwane Weather Station, Tembe Elephant Park, Maputaland, northern KwaZulu-Natal, South Africa $(b=$ height above sea level, $\mathrm{c}=$ duration of observations in years, $\mathrm{d}=$ mean annual temperature in ${ }^{\circ} \mathrm{C}$, e $=$ mean annual precipitation in $\mathrm{mm}, \mathrm{f}=$ mean daily minimum of the coldest month in ${ }^{\circ} \mathrm{C}, \mathrm{g}=$ lowest temperature recorded in ${ }^{\circ} \mathrm{C}$, $\mathrm{h}=$ mean daily maximum of warmest month in ${ }^{\circ} \mathrm{C}$, $\mathrm{i}=$ highest temperature recorded in ${ }^{\circ} \mathrm{C}, \mathrm{j}=$ mean daily temperature variation in ${ }^{\circ} \mathrm{C}, \mathrm{m}=$ dry season, $\mathrm{n}=$ humid season, $\mathrm{o}=$ mean monthly rainfall $>100 \mathrm{~mm}$ ) following Walter (Cox \& Moore 1994).

coastal plain date back approximately 5 million years to the early Pleistocene. The recent dunes are as young as 10000 years, from the late Pleistocene to 500 years ago for the current coastal dunes. The dunes of Maputaland are among the most recent geological formations that are found in southern Africa (Hobday 1976).

\section{Soils}

The soils of Tshanini Game Reserve are similar to those described by Matthews et al. (2001) for Tembe Elephant Park, and specifically so for the dunes and inter-dune depressions. The soils have a thin, organically enriched A-horizon underlain by a sandy subsoil. The clay content is attributed 
to the weathering of labile minerals over a long period. The soils along the two main dunes are similar to those described for the Nhlela Ridge in Tembe Elephant Park. The soils are well-drained profiles with less than $5 \%$ clay, have a high base status, and are classified as Hutton or Clovelly forms (Soil Classification Working Group 1991; Matthews et al. 2001). The inter-dune depressions are underlain by moderately to well-drained yellowish Clovelly or grey Fernwood soils (Soil Classification Working Group 1991; Matthews et al. 2001).

\section{Methods}

Aerial photographs were obtained from the Surveyor General in Pretoria, South Africa. The appropriate 1:50 000 scale photograph was scanned and digitised by using the Geographical Information Tool Cartalinx (The spatial Data Builder, Version 1.1. Clarks Laboratories, 1998) to create a Geographical Information System (GIS) based geo-referenced map of the homogeneous physiognomic and physiographic units of the reserve. The map was then refined by using the ArcView GIS tool (Arc View Gis, Version 3.1, Environmental Systems Research Institute 1998).

In all, 51 sample plots, of $30 \mathrm{~m} \times 30 \mathrm{~m}$ each, were distributed in a stratified random manner throughout the study area. Vegetation sampling was done from January to May 2001. The terminology that was used to name and describe the vegetation structure of the plant communities follows Edwards (1983). For each sample plot, a relevé of the floristic composition and cover-abundance values for each plant species, according to the Braun-Blanquet coverabundance scale (Mueller-Dombois \& Ellenberg 1974), were recorded. Environmental and ecological information collected for each sample plot included slope, aspect, altitude, topography, rock cover, erosion percentage, cover for canopy height classes of herbs, grasses, shrubs and trees and biotic influence. Unidentified plant species were sampled for later identification at the herbarium of the Tembe Elephant Park.

The floristic data were classified with Braun-Blanquet procedures using the Turboveg and Megatab computer packages (TURBOVEG for Windows version 1.97, Hennekens \& Schaminee 2001). This vegetation classification system was used to refine and interpret the preliminary map of homogeneous physiognomic units to produce a more detailed vegetation map of the Tshanini Game Reserve. As it appeared impossible to digitise every vegetation unit and subunit separately, some units were grouped in mosaics. These mapping units are indicated in Fig. 2.

The homogeneous vegetation units that are common to Tembe Elephant Park and Tshanini Game Reserve were then analysed further to determine the degree of similarity or dissimilarity in terms of species composition and abundance by using similarity indices as described by Mueller-Dombois \& Ellenberg (1974). The phytosociological table created for Tshanini Game Reserve and the table obtained from the study of Matthews et al. (2001) for Tembe Elephant Park were used to calculate the indices. Sorensen's qualitative index of similarity (MuellerDombois \& Ellenberg 1974) that is based on the absence or presence of plant species was used to calculate indices of similarity in plant species composition. To be able to do so, a similar number of comparable relevés were compared in each of the vegetation communities. The following equation was used:

Sorensen's Index of Similarity $=(2 \mathrm{c} \times 100) / \mathrm{A}+\mathrm{B}$ where:

$\mathrm{c}=$ number of species common to both communities

$\mathrm{A}=$ total number of species in community $\mathrm{A}$

$\mathrm{B}=$ total number of species in community $\mathrm{B}$.

The similarity index of Motyka et al. (Mueller-Dombois \& Ellenberg 1974) was used to calculate a quantitative similarity index in terms of species abundances. The equation is:

Motyka et al.'s Index of Similarity $=\left(2 \mathrm{M}_{\mathrm{W}} \mathrm{x} 100\right) /$ $\left(\mathrm{M}_{\mathrm{a}}+\mathrm{M}_{\mathrm{b}}\right)$

where:

$\mathrm{M}_{\mathrm{W}}$ refers to the sum of the smaller quantitative values of the species that are common to the two communities;

$M_{a}$ is the sum of the quantitative values of all the species in one community;

$\mathrm{M}_{\mathrm{b}}$ is the sum of all the quantitative values of all the species in the other community.

To calculate the values of $M_{w}, M_{a}$ and $M_{b}$, the Braun-Blanquet cover-abundance values in the phytosociological tables of both reserves were converted into mean cover percentages. To accomplish this each cover-abundance value on the Braun-Blanquet scale was replaced by a cover value, whereafter a mean for the community could be calculated. Although this is a crude method it does allow quan- 
Table 1

Classification of the vegetation communities for

Tshanini Game Reserve in northern KwaZulu-Natal, South Africa

1. The Urelytrum agropyroides-Sapium integerrimum open woodland

1.1. The Albizia versicolor-Diheteropogon amplectens sparse woodland

1.2. The Indigofera podophylla-Albizia adianthifolia ecotonal sparse woodland

1.3. The Antidesma venosum-Urelytrum agropyroides open woodland

1.4. The Fimbristylis complanata-Diheteropogon amplectens open woodland

2. The Sclerocarya birrea-Strychnos madagascariensis closed woodland

2.1. The Cordia monoica-Sclerocarya birrea open to closed woodland

2.2. The Melinis repens-Sclerocarya birrea closed woodland

3. The Ptaeroxylon obliquum-Hymenocardia ulmoides sand forest

3.1. The Rothmannia fischeri-Ptaeroxylon obliquum low to short sand forest

3.2. The Strychnos henningsii-Ptaeroxylon obliquum tall sand forest.

titative comparisons to be made. When comparing vegetation communities, the similarity in terms of absence or presence of species in two communities is more important than the quantitative contribution of each species to a community (Mueller-Dombois \& Ellenberg 1974). The latter can be used to refine the comparisons.

\section{Results and discussion}

\section{Classification}

Three major plant communities and eight sub-communities were identified for the Tshanini Game Reserve (Tables 1 \& 2, Fig. 2). The Tshanini Game Reserve lies on regic sand and no major geological feature could be identified that plays a role in the differentiation of the plant communities. Matthews et al. (2001) postulated that clay content, moisture level in the soil and vegetation dynamics were major determinants of vegetation differentiation in Tembe Elephant Park. However, clay content and moisture level differences in the soil of various areas in Tshanini Game Reserve are slight and could not be directly related to the differentiation between plant communities in Tshanini Game Reserve. Except for the sand forest, the plant communities do not have sharp boundaries. The open and closed woodlands form mosaics that grade into each other and the boundaries are difficult to map on an aerial photograph. However, the plant communities are relatively easily recognised in the field.

\section{Description of plant communities}

\section{The Urelytrum agropyroides-Sapium integerrimum open woodland}

This open woodland is the most widespread community in Tshanini Game Reserve. It is associated with the dunes and inter-dune depressions on grey-brown to orange-grey dystrophic regosols. These soils have a low clay content and are associated with a low $\mathrm{pH}$ value of 5.5 (Matthews et al. 2001). The open woodland covers $37.7 \%$ of Tshanini Game Reserve and represents a surface area of 912 ha.

This plant community is characterised by diagnostic species of Species Group E. Plant species of Species Group K form the link between this open woodland community and the closed woodland community. Diagnostic plant species are the tree Albizia adianthifolia, the grasses Diheteropogon amplectens and Urelytrum agropyroides and the shrub Acridocarpus natalitius var. linearifolius. 


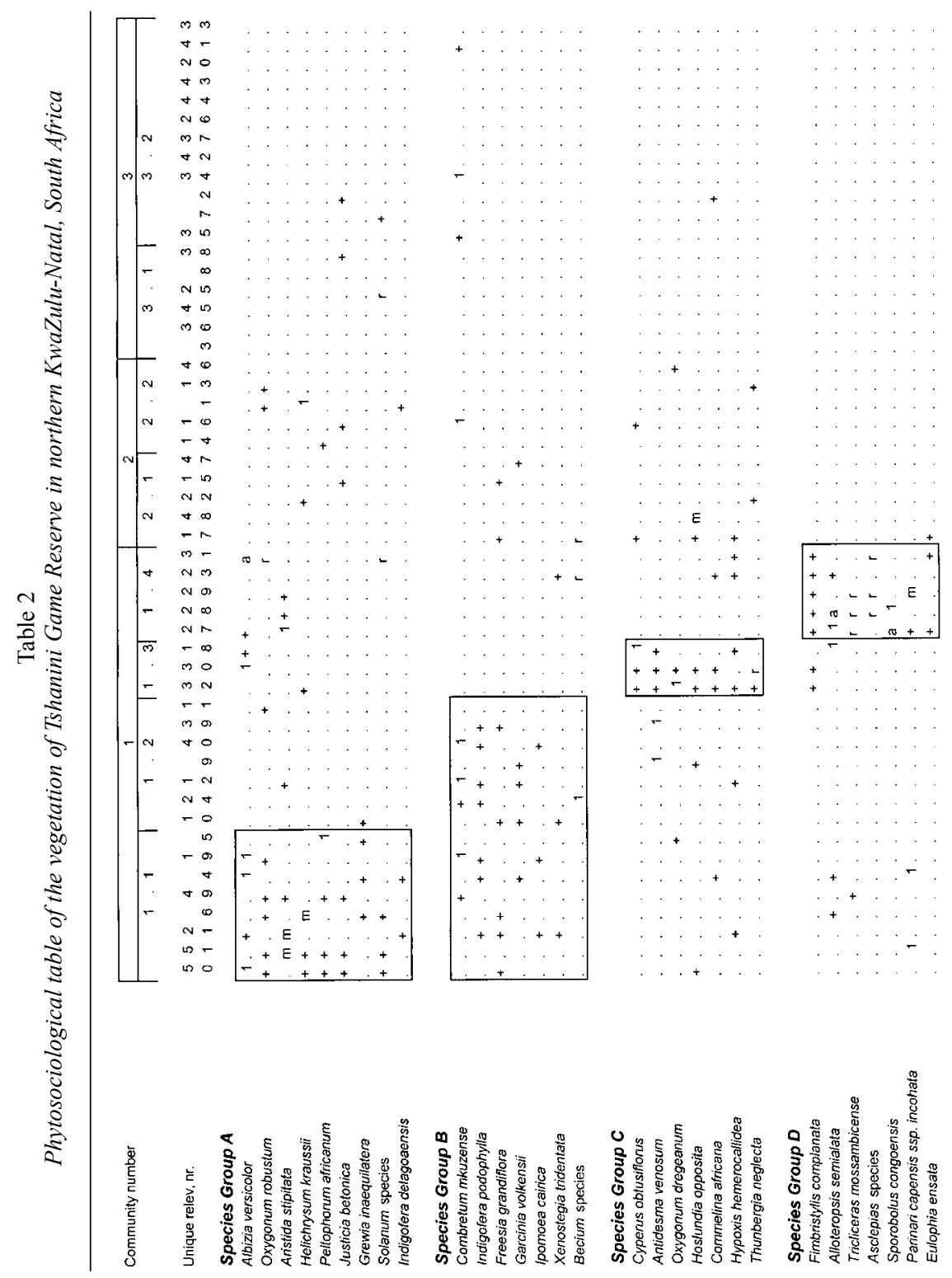




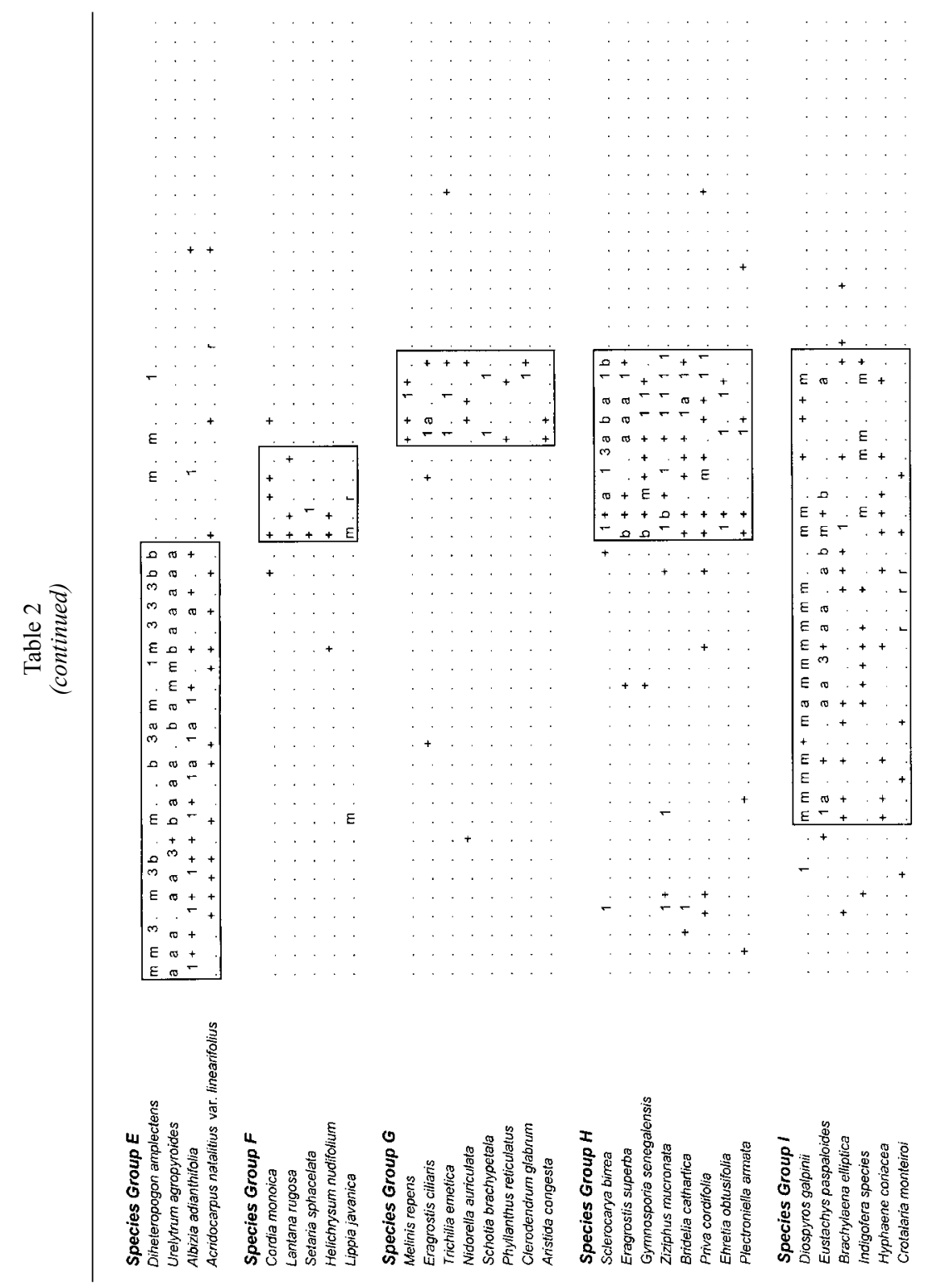



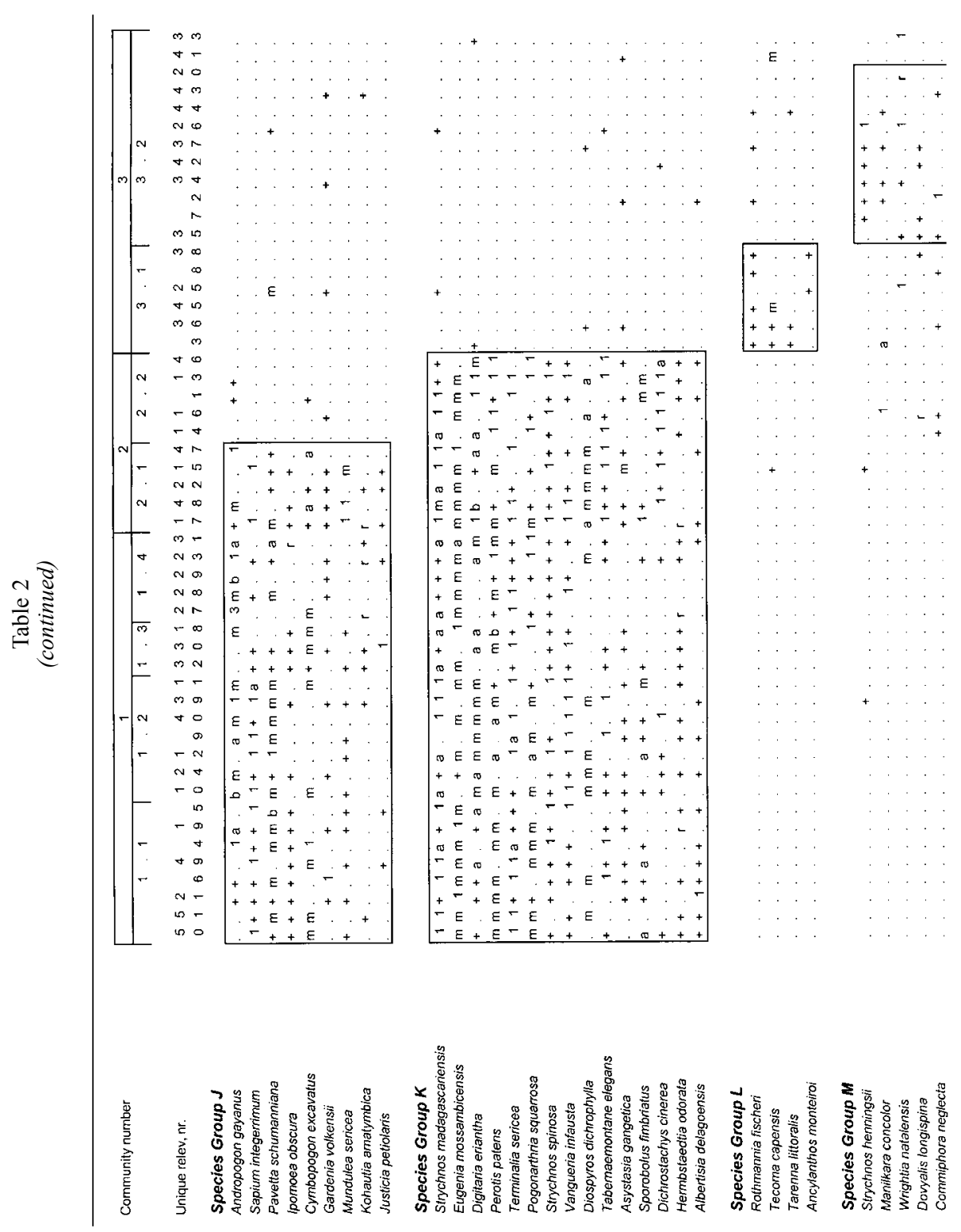


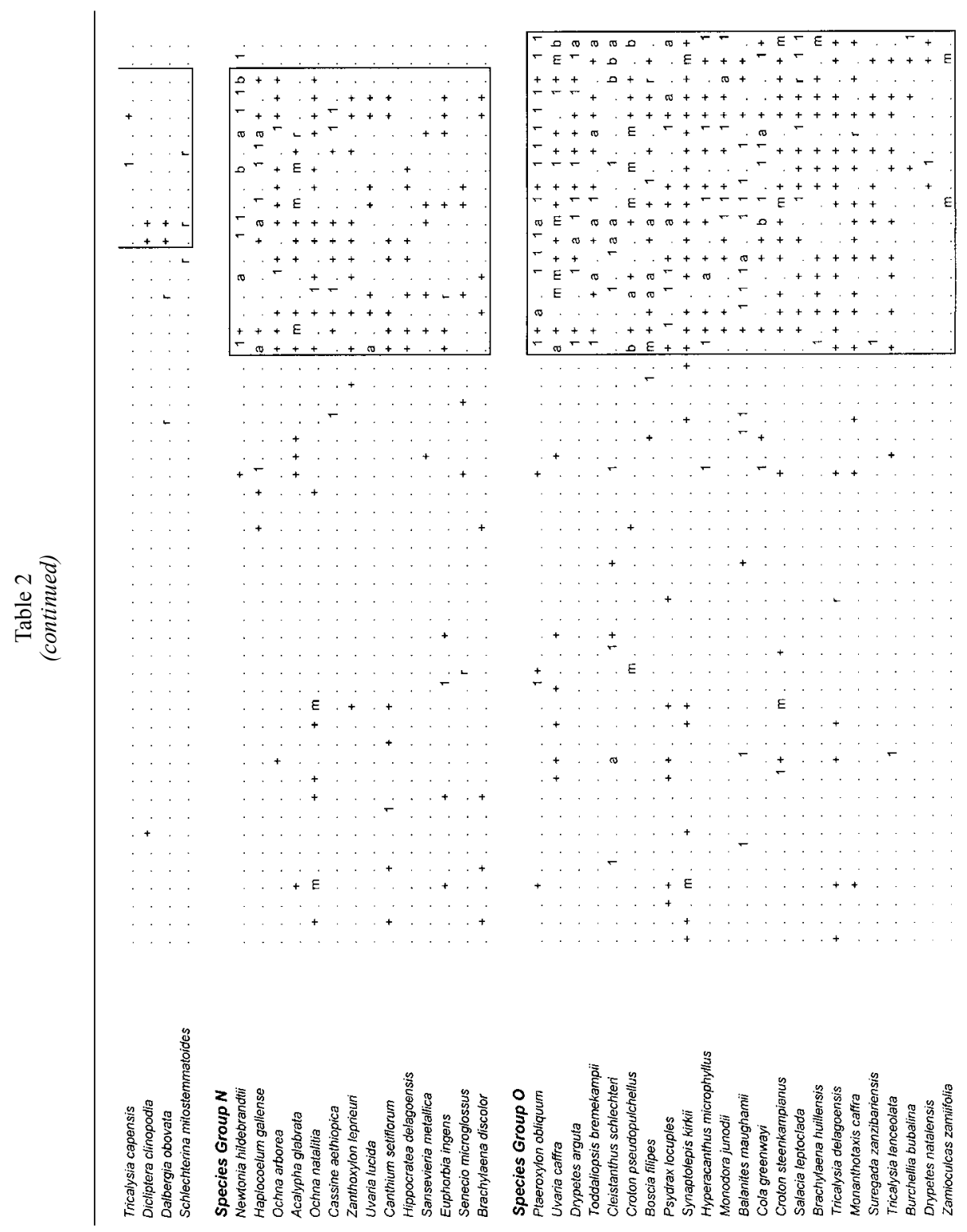




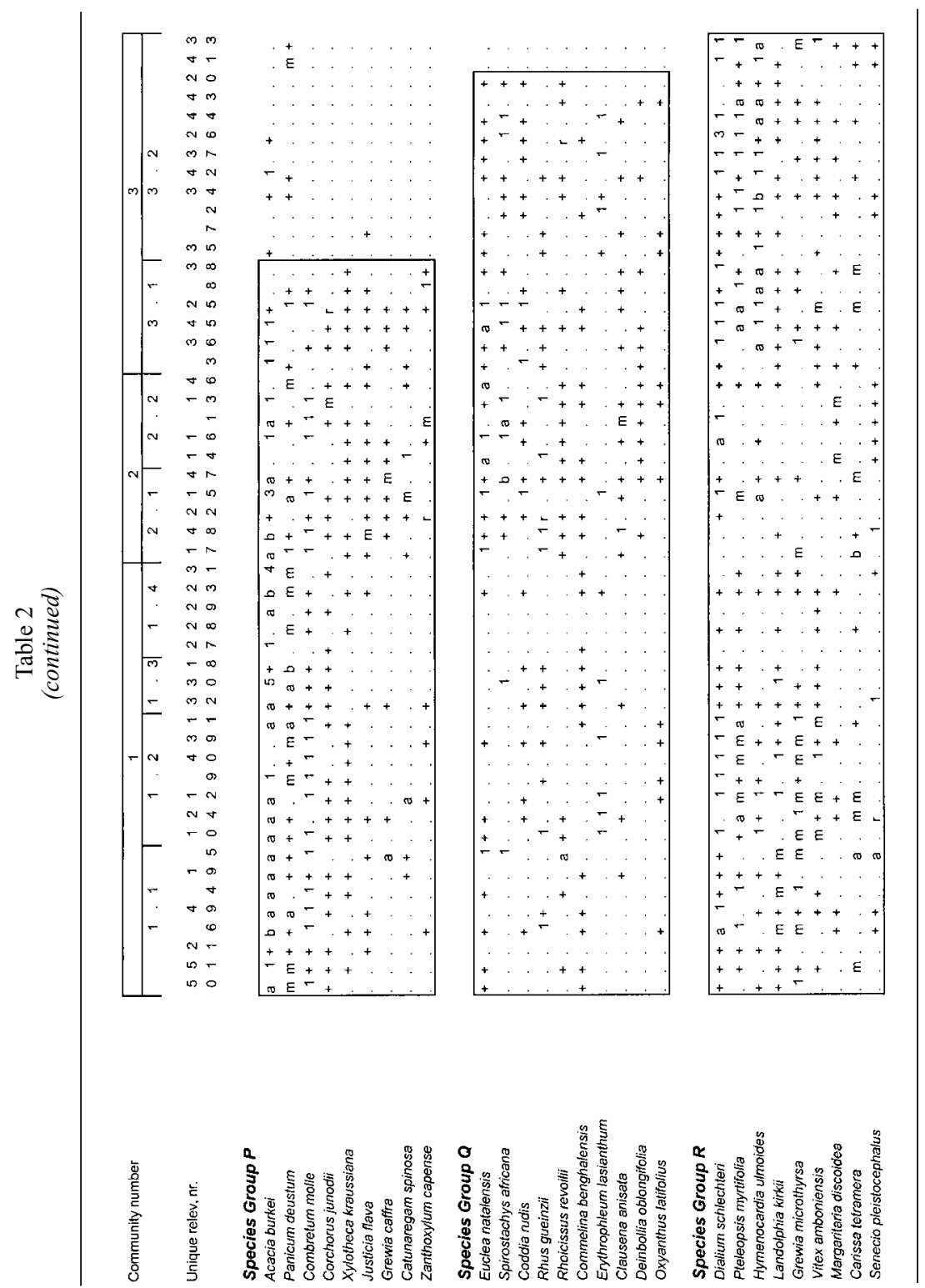


Prominent species with a constancy of $>50 \%$ include the shrub Vangueria infausta, the grass Andropogon gayanus and the trees Acacia burkei, Strychnos madagascariensis, Terminalia sericea, Combretum molle and Sapium integerrimum. The dwarf shrubs Pavetta schumanniana, Eugenia mossambicensis and the forb Corchorus junodii have a high constancy in this community (Table 2).

A mean of 45 species was recorded per relevé. Of the plant species that were recorded in this community, 18 species are endemic to Maputaland (Van Wyk 1996). Structurally, according to the classification of Edwards (1983) this community is a woodland that varies from sparse to open. The non-continuous canopy can reach heights of $10-12 \mathrm{~m}$, but a height of $6-8 \mathrm{~m}$ is the norm. This community is subdivided into four subcommunities based on the density, structure and floristic composition of the vegetation.

\subsection{The Albizia versicolor-Dihetero- pogon amplectens sparse woodland}

This subcommunity is found on the dune crests, slopes and inter-dune depressions of the western side of the Tshanini Game Reserve and occurs on acidic orange-grey dystrophic regosols. The subcommunity is characterised by the diagnostic species of Species Group A and common species of Species Groups E, J and K. The diagnostic species are the tree Albizia versicolor, the forb Oxygonum robustum and the shrub Grewia inaequilatera. Prominent species are the trees Albizia adianthifolia, Sapium integerrimum and Strychnos madagascariensis, the grasses Diheteropogon amplectens, Urelytrum agropyroides, Perotis patens and Pogonarthria squarrosa, the shrub Acridocarpus natalitius var. linearifolius and the dwarf shrubs Pavetta schumanniana, Eugenia mossambicensis and Albertisia delagoensis. A mean of 45 plant species was recorded per relevé. According to the classification of Edwards (1983), this subcommunity is a short sparse woodland with a few tall trees that reach a height of 6-8 $\mathrm{m}$. The tree layer is underlain by a short to tall grassland up to $2 \mathrm{~m}$ tall.

\subsection{The Indigofera podophylla-Albizia adianthifolia ecotonal sparse wood- land}

This subcommunity is also found on the dune crests, slopes and inter-dune depressions on the western portion of the Tshanini Game Reserve on acidic orange-grey dystrophic regosols. The subcommunity is not characterised by its own distinct Species Group but shares Species Group B with community 1.1. Prominent species in this community are found in Species Groups E, J and $\mathrm{K}$. This subcommunity forms a transition zone linking the sparse and open woodlands. Diagnostic species are the tree Combretum mkuzense and the shrubs Garcinia livingstonei and Indigofera podophylla. The prominent species include the trees Albizia adianthifolia, Sapium integerrimum and Strychnos madagascariensis, the grasses Diheteropon amplectens, Urelytrum agropyroides, Perotis patens, Digitaria eriantha and Pogonarthria squarrosa, the shrub Acridocarpus natalitius var. linearifolius and dwarf shrubs Pavetta schumanniana, Eugenia mossambicensis and Albertisia delagoensis. A mean of 46 plant species was recorded per relevé. According to the classification of Edwards (1983), this subcommunity is a short sparse woodland, with a few tall trees that reach a height of 6-8 $\mathrm{m}$. The tree layer is underlain by a short to tall grassland up to $2 \mathrm{~m}$ tall.

\subsection{The Antidesma venosum-Urelytrum agropyroides open woodland}

This subcommunity is found on the dune crests, slopes and inter-dune depressions on the western portion of the Tshanini Game Reserve. It occurs on acidic orange-grey dystrophic regosols and is characterised by diagnostic species of Species Group $\mathrm{C}$ with common species of Species Groups E, I, J and $\mathrm{K}$. The diagnostic species are the tree Antidesma venosum, the forbs Oxygonum dregeanum and Hoslundia opposita, the 
sedge Cyperus obtusiflorus and geophyte Hypoxis hemerocallidea. The prominent species are the trees Albizia adianthifolia, Sapium integerrimum and Strychnos madagascariensis, the grasses Diheteropogon amplectens, Urelytrum agropyroides, Eustachys paspaloides and Perotis patens, the shrub Acridocarpus natalitius var. linearifolius and dwarf shrubs Eugenia mossambicensis and Diospyros galpinii. A mean of 52 plant species was recorded per relevé. This makes this plant subcommunity the second richest unit sampled in the Tshanini Game Reserve. According to the classification of Edwards (1983), this subcommunity is a short open woodland with a few tall trees that reach a height of 6-8 m. The tree layer is underlain by a short to tall grassland up to $2 \mathrm{~m}$ tall.

\subsection{The Fimbristylis complanata- \\ Diheteropogon amplectens open woodland}

This subcommunity is found on the dune crests, slopes and inter-dune depressions on the western portion of the Tshanini Game Reserve. It occurs on acidic orange-grey dystrophic regosols (Matthews et al. 2001). The subcommunity is characterised by the diagnostic species of Species Group D with common species in Species Groups E, I, J and $\mathrm{K}$. The diagnostic species are the sedge Fimbristylis complanata, the dwarf shrub Parinari capensis subsp. incohata, the forb Tricliceras mossambicense and the grass Alloteropsis semialata. The prominent species are the trees Albizia adianthifolia and Strychnos madagascariensis, the grasses Diheteropogon amplectens, Urelytrum agropyroides, Eustachys paspaloides, Perotis patens and Pogonarthria squarrosa, the shrub Acridocarpus natalitius var. linearifolius and the dwarf shrub Eugenia mossambicensis. A mean of 37 plant species was recorded per relevé. According to the classification of Edwards (1983), this subcommunity is a short open woodland with a few tall trees that reach a height of 6-8 $\mathrm{m}$. The tree layer is underlain by a short to tall grassland up to $2 \mathrm{~m}$ tall.
2. The Sclerocarya birrea-Strychnos madagascariensis closed woodland

In the Tshanini Game Reserve the closed woodland community is associated with the dunes and inter-dunes depressions and occurs on grey dystrophic regosols. The soils have a low clay content associated with a low $\mathrm{pH}$ value of 5.5 (Matthews et al. 2001). The closed woodland covers $19.1 \%$ of the Tshanini Game Reserve and represents a surface area of 463 ha.

This plant community is characterised by species of Species Group H. Diagnostic plant species are the trees Sclerocarya birrea, Ziziphus mucronata and Bridelia cathartica, the grass Eragrostis superba, the shrub Gymnosporia senegalensis and forb Priva cordifolia. Prominent species with a constancy $>50 \%$ include the shrubs Vangueria infausta and Diospyros dichrophylla, the trees Strychnos madagascariensis, Strychnos spinosa, Euclea natalensis and Tabernaemontana elegans and the grasses Digitaria eriantha, Perotis patens and Pogonarthria squarrosa (Table 2).

A mean of 52 plant species was recorded per relevé. Of the plant species that were recorded in this community, 15 species are endemic or near endemic to Maputaland (Van Wyk 1996). According to the classification of Edwards (1983), this community is a short, open to closed woodland that can be distinguished by a semi-continuous to continuous canopy reaching heights from 6-10 m. A tall to high shrub component, which forms dense clumps around the base of trees, is associated with this community. The tree and shrub canopies are underlain by a continuous mixed layer of short grasses and herbs. This community is subdivided into two subcommunities based on the structure and floristic composition of the vegetation.

\subsection{The Cordia monoica-Sclerocarya birrea open to closed woodland}

This subcommunity is found on the dune crests, slopes and inter-dune depressions in the eastern half of the Tshanini Game Reserve on acidic grey-brown dystrophic 
regosols. It is characterised by diagnostic species of Species Group F with common species of Species Groups H, I and K. This subcommunity is usually found around ancient settlements and shows a slow recovery from human impact. Old settlements can still be located and trees grow back on the former cultivated lands around these emplacements. The outline of the old fields is still distinguishable from surrounding vegetation. The diagnostic species are the shrubs Cordia monoica, Lantana rugosa and Lippia javanica, the herb Helichrysum nudifolium and the grass Setaria sphacelata. Prominent species are the trees Sclerocarya birrea, Ziziphus mucronata, Tabernaemontana elegans and Strychnos madagascariensis, the grasses Eragrostis superba, Digitaria eriantha and Perotis patens, the shrubs Gymnosporia senegalensis, Strychnos spinosa, Bridelia cathartica and dwarf shrub Eugenia mossambicensis. A mean of 56 plant species was recorded per relevé, which makes it the richest plant subcommunity sampled in the Tshanini Game Reserve. According to the classification of Edwards (1983), this subcommunity is a short, open to closed woodland with a semi-continuous canopy, reaching heights of $8-10 \mathrm{~m}$. The tree layer is underlain by tall to high shrubs as well as a continuous grass layer up to $1 \mathrm{~m}$ tall.

\subsection{The Melinis repens-Sclerocarya birrea closed woodland}

This subcommunity is found on the dune crests, slopes and inter-dune depressions in the eastern half of the Tshanini Game Reserve. It occurs on acidic grey-brown dystrophic regosols. This subcommunity is characterised by diagnostic species of Species Group G, with common species in Species Groups H, I and K. The diagnostic species are the tree Trichilia emetica, the shrub Phyllanthus reticulatus, the herb Nidorella auriculata and the grasses Melinis repens and Eragrostis ciliaris. Prominent species are the trees Sclerocarya birrea, Ziziphus mucronata, Tabernaemontana elegans and Strychnos madagascariensis, the grasses Eragrostis superba, Digitaria eriantha and Perotis patens, the shrubs Gymnosporia senegalensis, Strychnos spinosa and Bridelia cathartica and dwarf shrub Eugenia mossambicensis. A mean of 48 plant species was recorded per relevé. According to the classification of Edwards (1983), this subcommunity is a short closed woodland with a semi-continuous to continuous canopy reaching a height of $8-10 \mathrm{~m}$. The tree layer is underlain by a mixed short layer of grasses and herbs as well as tall to high shrubs.

\section{The Ptaeroxylon obliquum-Hymenocar- dia ulmoides sand forest}

The sand forest is a major community in Tshanini Game Reserve. It is associated with the dunes and inter-dunes depressions on orange-brown arenosols and dystrophic regosols. The soils have a low clay content associated with a low $\mathrm{pH}$ value of 5.6 (Matthews et al. 2001). The sand forest covers $43.2 \%$ of Tshanini Game Reserve and represents a surface area of 1045.5 ha.

This plant community is characterised by diagnostic species of Species Group O. Consistent diagnostic species are the tree Ptaeroxylon obliquum, the shrub or liana Uvaria caffra, the understorey shrubs Drypetes arguta and Toddaliopsis bremekampii. Prominent species with a constancy of $>50 \%$ include the shrubs Croton pseudopulchellus, Hyperacanthus microphyllus, Monodora junodii, Salacia leptocla$d a$ and Croton steenkampianus, the trees Cleistanthus schlechteri, Hymenocardia ulmoides, Pteleopsis myrtifolia, Brachylaena huilensis and Balanites maughamii. The understorey shrub Synaptolepis kirkii has a high constancy in this community (Table 2 ).

A mean of 40 plant species was recorded per relevé. Of the plant species that were recorded, 20 species are endemic to Maputaland with 10 species restricted to the Sand Forest type (Van Wyk 1996; Matthews et al. 2001). According to the classification of Edwards (1983), this community is classified as a forest, with a closed canopy reaching heights from $5 \mathrm{~m}$ for the low sand forest subcommunity to $12 \mathrm{~m}$ for the tall sand forest subcommunity. This community is subdivided into 
two subcommunities based on the structure and floristic composition of the vegetation.

\subsection{The Rothmannia fischeri-Ptaeroxy- lon obliquum low to short sand forest}

This subcommunity is found on the dune crests, slopes and inter-dune depressions throughout the Tshanini Game Reserve on acidic orange-brown arenosols and dystrophic regosols. It is characterised by diagnostic species of Species Group L and common species of Species Groups N and O. The diagnostic species are the tree Rothmannia fischeri, the creeper Tecoma capensis and the shrub Tarenna littoralis. Prominent species are the trees Ptaeroxylon obliquum, Balanites maughamii, Brachylaena huilensis, Pteleopsis myrtifolia and Hymenocardia ulmoides, the lianas Uvaria caffra, Uvaria lucida and Hippocratea delagoensis, the shrubs Ochna natalitia, Boscia filipes and Hyperacanthus microphyllus. The understory shrub Synaptolepis kirkii has a high constancy in this subcommunity. A mean of 48 plant species was recorded per relevé. According to the classification of Edwards (1983), this subcommunity is a low to short forest with a continuous canopy that reaches a height of 5-7 m. The understory is dense and nearly impenetrable with no intermediate strata between the canopy and ground. At ground level a low, semi-continuous layer of mixed grass and herbs is found.

There is a controversy regarding the forest status of the low sand forest. The low canopy associated with the absence of secondary intermediate canopy strata suggests that this subcommunity should be classified as tall thicket as defined by Low \& Rebelo (1998). Izidine et al. (2003) suggest that such vegetation types should be named Licuati thicket.

\subsection{The Strychnos henningsii-Ptaeroxy- lon obliquum tall sand forest}

This subcommunity is found on the dune crests, slopes and inter-dune depressions throughout the Tshanini Game Reserve. It occurs on low clay content, acidic orangebrown arenosols and dystrophic regosols. This subcommunity is characterised by diagnostic species of Species Group M and common species of Species Groups N and O. The diagnostic species are the trees Strychnos henningsii, Manilkara concolor and Wrightia natalensis, the shrubs Dovyalis longispina, Commiphora neglecta and Tricalysia capensis. Prominent species are the trees Ptaeroxylon obliquum, Newtonia hildebrandtii, Haplocoelum gallense, Ochna arborea, Brachylaena huilensis and Monodora junodii, the lianas Uvaria caffra, Uvaria lucida and Hippocratea delagoensis, the shrubs Ochna natalitia, Drypetes arguta, Toddaliopsis bremekampii, Salacia leptoclada, Monanthotaxis caffra and Hyperacanthus microphyllus. A mean of 39 plant species was recorded per relevé. According to the classification of Edwards (1983), this subcommunity is structurally a tall forest with a closed canopy that reaches a height of 12-15 $\mathrm{m}$ for the largest and oldest trees. An intermediate canopy of smaller trees and high shrubs reaches heights of 5-6 m. The ground level is covered with a semi-continuous layer of low to short herbs. The forest is relatively open and easy to walk through. Izidine et al. (2003) suggest that such vegetation types should be named Licuati forest.

The Nhlole seepage line area was not sampled and has to be investigated further. It appears that the seepage line may have a duplex soil and that the vegetation type along the Nhlole should be similar to the Spirostachys africana-Berchemia zeyheri closed woodland on duplex soils described by Matthews et al. (2001). This area has been mapped as woodland on clay in Fig. 2.

\section{Similarity indices}

The concept of some degree of similarity or dissimilarity between plant communities is difficult to quantify. It is however, possible to use mathematical models to describe such relationships, but because of the mathematical nature of these models, arbitrary limits have to be set (Mueller-Dombois \& Ellen- 
Table 3

A comparison between the vegetation of Tembe Elephant Park and Tshanini Game Reserve by means of the Sorensen Similarity Index based on species composition and that of

Motyka et al. (In: Mueller-Dombois \& Ellenberg 1974) based on species abundance

\begin{tabular}{lcc}
\hline Vegetation type & $\begin{array}{c}\text { Species composition: } \\
\text { presence-absence data }\end{array}$ & $\begin{array}{c}\text { Species abundance: } \\
\text { cover-abundance data }\end{array}$ \\
\hline Open woodland & $50.9 \%$ & $31.8 \%$ \\
Closed woodland & $53.4 \%$ & $26.8 \%$ \\
Sand Forest & $54.6 \%$ & $39.0 \%$ \\
\hline
\end{tabular}

berg 1974). Several indices have been used in the past to quantify the degree of similarity between homogeneous vegetation units or plant communities. Jaccard's Similarity Index is a simple mathematical expression that is based on the ratio of the plant species that are common to two communities, and the total number of species present. Sorensen's Similarity Index is an evolution of Jaccard's and is also used to compare vegetation communities on the basis of the absence or presence of species. The Similarity Index of Motyka et al. (Mueller-Dombois \& Ellenberg 1974) is a modification of the Sorensen Similarity Index and is designed to treat data on vegetation structure by quantifying each species that is present (Mueller Dombois \& Ellenberg 1974). To interpret similarity indices based on the absence or presence of species, Mueller-Dombois \& Ellenberg (1974) suggest that a $25 \%$ up to $50 \%$ overlap in species indicates similar vegetation communities, with $25 \%$ as the lower threshold below which communities are considered as different. Similarity indices exceeding $50 \%$ show that the two vegetation communities are so similar that more fieldwork might be necessary to obtain ecologically meaningful information (Mueller Dombois \& Ellenberg 1974).

The vegetation units from Tembe Elephant Park that were used in this comparison are described by Matthews et al. (2001) as:

- The Drypetes arguta-Uvaria lucida subsp. virens sand forest community of the deep sandy areas (dry sands)
- The Acacia burkei-Euclea natalensis closed woodland and thicket subcommunity

- The Salacia kraussii-Themeda triandra open woodland on sand subcommunity

The similarity indices indicate that the three main plant communities of Tshanini Game Reserve are similar to their equivalent plant communities and subcommunities described for Tembe Elephant Park (Table 3). These results therefore confirm the prediction made by Matthews et al. (2001) that the plant communities that were described for Tembe Elephant Park can be extrapolated to other parts of Maputaland and can be used for further planning and development of Tshanini Game Reserve and any other similar areas.

The qualitative similarity in species composition between the two sets of data is exceptionally high (Table 3 ). However, the quantitative similarity indices suggest that there are more pronounced differences between the two reserves. The Tembe Elephant Park has been protected from human utilisation since 1983, although various wildlife species were introduced or re-established there. The Tshanini Game Reserve on the other hand has been devoid of most forms of wildlife for a similar period of time, but it has been subject to human utilisation, cattle grazing and the associated fire regime, especially in the sparse to open woodland areas where grassland occurs. The leaders from the community of Manqakulane still allow cattle grazing on the land of the Tshanini Game Reserve. 
As a result, small cattle herds still roam the reserve, especially in the open woodlands. The cattle are herded to and from the centre of the community through small tracks cut through the bush, usually avoiding the sand forest vegetation type. The cattle herders have also been observed repeatedly burning the open woodland areas in Tshanini Game Reserve to keep the grass green for the cattle.

The high similarity in plant species composition between the two reserves, despite the different utilisation regimes over a period of 19 years is noteworthy. Although no factual data on human population numbers and the intensity of their use of natural resources are available, various authorities in the northern Maputaland region agree that both have increased over the past 19 years. The degree of similarity that still exists in the plant resources suggests that either the human presence and utilisation of these resources in Tshanini Game Reserve has been consistently low, or that the wildlife utilisation in Tembe Elephant Park has been high, or that both forms of utilisation lead to the same pressure on the species.

However, the lower similarity between the two reserves when a quantitative measure is used suggests that there are differences in terms of cover of the species. The sand forest community in Tshanini Game Reserve has a significantly higher mean cover value per species than the equivalent community in Tembe Elephant Park $(t=5.65, d f=8, p<$ $0.001)$. Although the species composition has remained relatively unchanged in both reserves, the sand forest vegetation in the Tshanini Game Reserve is denser than in Tembe Elephant Park. The assumption made by Van Rensburg et al. (1999) that the sand forest around the park suffers the same from human pressure as from elephant impact inside the park may not be true as the distance from the forest to human settlements increases. The present study suggests that elephants may be affecting the sand forest in Tembe Elephant Park and that they have already changed the plant cover significantly but not the species composition.
Concerning the closed woodland the similarity index is high in terms of plant species composition but is greatly reduced in terms of species cover indicating a definite difference in closed woodland structure between Tshanini Game Reserve and Tembe Elephant Park. The mean species cover value for the closed woodlands in Tshanini Game Reserve is significantly higher than for Tembe Elephant Park $(t=7.62, d f=9, p<0.001)$. The larger mammals found in Tembe Elephant Park are unlikely to have used the Tshanini Game Reserve intensively at any stage in the past due to the absence of standing water. Utilisation of Tshanini Game Reserve was probably limited to migratory incursions from larger forms of wildlife, which must have been restricted in time and impact. Small cattle herds, which have supplanted the wildlife in Tshanini Game Reserve, prefer the more open woodland areas as opposed to the closed woodland and sand forest. The cattle herds were mostly observed walking through the closed woodland from one open woodland area to another. It therefore appears unlikely that the cattle herds could create a noticeable impact on the vegetation of the closed woodland community. The lower cover values in the closed woodland community in Tembe Elephant Park may indicate that this vegetation type has been subjected to a high pressure from the wildlife since the complete fencing of the park in 1989. A similar phenomenon was reported in grazing exclosures where species diversity remained similar, but plant density and cover increased (Lenzi-Grillini et al. 1996). In areas that are subjected to animal utilisation and especially elephant presence, a decrease in vegetation cover and density is often observed. This is especially true when the stocking density of animals is higher than the ecological capacity, or the areas are close to natural or artificial watering points (Brits et al. 2002, Mapaure \& Campbell 2002, Mosugelo et al. 2002). Further research is needed to compare utilisation pressure and patterns by cattle herds in Tshanini Game Reserve with wildlife in Tembe Elephant Park. 
The similarity between the open woodland of the two reserves is once again noticeable in terms of plant species composition, but suggests a difference at the species abundance level. The mean species cover value for the open woodlands in Tshanini Game Reserve is significantly higher $(t=12.45$, $d f=18, p<0.001)$ than for Tembe Elephant Park. This difference can possibly be linked to the absence of wildlife in Tshanini Game Reserve combined with the improper use of fire. It is unlikely that the small cattle herds that roam the open woodland of the Tshanini Game Reserve now have had a noticeable impact on the vegetation. However, the higher density of the woody vegetation in Tshanini Game Reserve may also be interpreted as a sign of bush encroachment. The repeated burning of the grass layer of the open and sparse woodland by the cattle herders to stimulate out of season growth might provide conditions favourable for bush encroachment (Van Rooyen 2002). Cattle and wildlife have notoriously different requirements and impact on the vegetation (Bothma 2002). Moreover, the absence of the whole range of grazers and browsers in Tshanini Game Reserve combined with the absence of tree damaging animals could also provide conditions favourable for the increase in density of the woody component in the open woodland. The improper use of fire and to a lesser extent cattle grazing as opposed to high intensity wildlife utilisation are suggested as probable causes for the difference observed in species cover between the open woodland of the two reserves.

The trends observed in this study differ from those that were suggested by Van Rensburg et al. (1999) and verified by McGeoch et al. (2002) working with a suite of dung beetle species as bio-indicators. Van Rensburg et al. (1999) suggested that the impact of elephants on sand forest structure inside Tembe Elephant Park was comparable to the human impact outside the park. When selecting sites outside conserved areas, Van Rensburg et al. (1999) and McGeoch et al. (2002) concentrated on the populated areas within close proximity of Tembe Elephant Park. They attributed the change in the sand forest struc- ture immediately around the park to an increase in human utilisation of these resources. The changes recorded mainly involved the opening up of the canopy in the sand forest, an action they deemed was comparable to the opening up of the canopy by elephants in Tembe Elephant Park.

In the rural community of Manqakulane the situation appears to differ from that described by Van Rensburg et al. (1999), possibly because of the remoteness of the Tshanini Game Reserve as opposed to areas adjacent to Tembe Elephant Park. The latter areas are served by the main road that has become an extraction route for construction wood and especially for firewood. The vegetation adjacent to the road is also harvested for the sale of wood. Human settlements are found up to $2 \mathrm{~km}$ south of the main road that passes along the southern boundary of the Tembe Elephant Park. Impact on vegetation surrounding human settlements can be observed as far as $2 \mathrm{~km}$ from the settlement location.

The interpretation of the vegetation data suggests that the present human pressure on the Tshanini Game Reserve in northern Maputaland is still low. There is no doubt that the pressure is increasing because of the population increase over the past 10 years $(\mathrm{H}$. Els, Centre for Indigenous Knowledge, University of Pretoria, 0002 Pretoria pers. comm.). However, local people prefer to remain close to the water resources, main roads and arable lands. A low potential for agriculture, the distance from a major road and a lack of water have all kept people away from Tshanini Game Reserve. These factors have therefore contributed to the preservation of this environment. The distance of the Tshanini Game Reserve from the community centre, where most people of the community of Manqakulane have settled, is less than $3 \mathrm{~km}$. However, this distance in such a poor community where vehicles and other means of transportation of goods and resources are not readily available, seems to be sufficient to prevent an excessive impact on the reserve from human utilisation. Most people have to carry the material which they harvest them- 
selves, often as loads on their head, and this seems to have limited the utilisation of resources further than the immediate vicinity of the settlements. The availability of adequate material for human utilisation in the immediate vicinity of human settlements may also have contributed to the protection of land further away. However, there are indications that a limit of sustainable utilisation has been reached in the vicinity of the human settlements, as suggested by Van Rensburg et al. (1999), and that the people in this community may soon seek to utilise the plant resources further away (Gaugris unpublished data 2003).

\section{Conclusions}

A vegetation map for Tshanini Game Reserve and its surrounding areas has been provided. Moreover, the plant communities have been described, and were compared with similar vegetation units in Tembe Elephant Park. This comparison between similar vegetation units shows that species composition is very similar but that plant cover values are significantly higher in Tshanini Game Reserve than in Tembe Elephant Park. These differences will have to be investigated in more detail to establish which condition should be regarded as representative of pristine conditions. The present study suggests that the sand forest in Tshanini Game Reserve has not suffered degradation by human pressure, but that elephants may be affecting the sand forest in Tembe Elephant Park and that they have already changed the plant cover significantly but not the species composition. In general the high intensity wildlife utilisation, notably by elephant, in Tembe Elephant Park is suggested as probable cause for the difference observed in species cover between equivalent communities of the two reserves. The Manqakulane community is still reasonably small and natural resource use is restricted to the vicinity of the settlements. This has apparently preserved large areas from been overexploited.

\section{Acknowledgements}

We are grateful to Thabani Mthembu, who assisted with the fieldwork, the people from the community of Manqakulane for authorising the research to be conducted on their land, the management staff from Tembe Elephant Park and the Ezemvelo KwaZuluNatal Wildlife for the use of the research facilities and the logistical support, the Centre for Wildlife Management, Prof. H. Els and the Centre for Indigenous Knowledge from the University of Pretoria for the material and financial support of the project. This material is also based upon work supported by the National Research Foundation under Grant Number 2047386.

\section{References}

Bothma, J. DU. P. 2002. Combining wild and domestic herbivores. Pp. 201-208. In: BотнмA, J. DU P. (ed.). Game Ranch Management. Pretoria: Van Schaik.

Brits, J., M.W. Van Rooyen, \& N. Van Rooyen. 2002. Ecological impact of large herbivores on the woody vegetation at selected watering points on the eastern basaltic soils in the Kruger National Park. African Journal of Ecology 40: 53-60.

Cox, C.B. \& P.D. Moore. 1994. Biogeography: an ecological and evolutionary approach. 5th ed. Oxford: Blackwell Scientific Publishing.

EDWARDS, D. 1983. A broad scale structural classification of vegetation for practical purposes. Bothalia 14: 705-712.

Hennekens, S.K. \& H.J. Schaminee. 2001. TuRBOVEG, a comprehensive data base management system for vegetation data. Journal of Vegetation Science 12: 589-591.

HoBDAY, D.K. 1976. Quarternary sedimentation and the development of the lagoonal complex, Lake St Lucia, Zululand. Annals of the South African Museum 71: 93-113.

Izidine, S., S. Siebert \& A.E. van WyK. 2003. Maputaland's licuati forest and thicket, botanical exploration of the coastal plain south of Maputo Bay, with an emphasis on the Licuati Forest Reserve. Veld \& Flora 89: 56-61.

Kirkwood, D. \& J.J. Midgley. 1999. The floristics of Sand Forest in northern KwaZulu-Natal, South Africa. Bothalia 29: 293-304.

LenZi-Grillini, C.R., P. Viskanic \& M. MaPesa. 1996. Effects of 20 years of grazing exclusion in an area of the Queen Elizabeth National Park, Uganda. African Journal of Ecology 34: 333-341. 
Low, A.B. \& A.G. Rebelo. 1998. Vegetation of South Africa, Lesotho and Swaziland. Pretoria: Department of Environmental Affairs \& Tourism.

MacDevette, D.R., D.K. MacDevette, I.G. GorDON. \& R.L.C. BARTHOLOMEW. 1989. Floristics of the Natal indigenous forests. Pp. 124-144. In: Geldenhuys, E.C.J. (ed.). Biogeography of the Mixed Evergreen Forests of Southern Africa. Pretoria: Foundation for Research Development. (Ecosystems Programmes Occasional report; no 45.).

Mapaure, I. \& B.M. Campbell. 2002. Changes in miombo woodland cover in and around Sengwa Wildlife Research Area, Zimbabwe, in relation to elephants and fire. African Journal of Ecology 40: 212-219.

Matthews, W.S., A.E. Van WyK, N. Van RoOyen. \& G.A. BотнA. 2001. Vegetation of the Tembe Elephant Park, Maputaland, South Africa. South African Journal of Botany 67: 573-594.

McGeogh, M.A., B.J. Van Rensburg \& A. Botes. 2002. The verification and application of bioindicators: a case study of dung beetles in a savanna ecosystem. Journal of Applied Ecology 39: 661-672.

MoLL, E.J. 1977. The vegetation of Maputaland-a preliminary report of the plant communities and their future conservation status. Trees in South Africa 29: 31-58.

Mosugelo, D.K., S.R. Moe, S. Ringrose \& C. Nelleman. 2002. Vegetation changes during a
36 year period in northern Chobe National Park, Botswana. African Journal of Ecology 40: 232-240.

Mueller-Dombois, D. \& H. EllenBerg. 1974. Aims \& Methods of Vegetation Ecology. New York: John Wiley.

Soll Classification Working Group. 1991. Soil Classification a taxonomic system for South Africa. Memoirs of the Agricultural Natural Resources of South Africa No. 15. Pretoria: Department of Agricultural Development.

Van Rensburg, B.J., M.A. Mcgeogh, S.L. Chown \& A.S. VAN JAARSVELD. 1999. Conservation of heterogeneity among dung beetles in the Maputaland Centre of Endemism, South Africa. Biological Conservation 88: 145-153.

Van Rooyen, N. 2002. Veld Management in the savannas. Pp. 571-620. In: BothMA, J. DU P. (ed.). Game Ranch Management. Pretoria: Van Schaik.

VAN WyK, A.E. 1996. Biodiversity of the Maputaland Centre. Pp. 198-207. In: VAN DER MAESEN, L.J.G., X.M. VAN DEN BURGT \& J.M. VAN MEDENBACH DE RoOY (eds.). The biodiversity of African Plants. Dordrecht: Kluwer Academic Publishers.

VAN WyK, A.E. \& G.F. Smith. 2001. Regions of floristic endemism in southern Africa. A review with emphasis on succulents. Pretoria: Umdaus. 